\title{
The Mediating Effects of Product Returns on the Relationship between Green Capabilities and Closed-Loop Supply Chain Adoption
}

\begin{abstract}
This research explores the mediating effects of product returns on the relationship between a firm's green capabilities and its adoption of closed-loop supply chain. Green capability is characterized in terms of product recovery, supply chain integration, and environmentally friendly manufacturing. A structural equation model using survey data drawn from ISO 14001 certified manufacturers in Malaysia is used to test the research hypotheses. The results reveal that recovery and integration capabilities positively influence product returns, while manufacturing and integration capabilities and product returns influence closed loop supply chain adoption. The results also indicate that the volume, type, timing, and quality of product returns partially mediate relationships between recovery and integration capabilities and closed-loop supply chain adoption. The findings highlight the importance of taking into account the complexities of product returns as part of efforts to increase the effects of green capabilities on closed-loop supply chain adoption.
\end{abstract}

Keywords: Green Capabilities, Product Returns, Closed-Loop Supply Chain, Environmental, Mediator 


\section{Introduction}

Over the last decade, manufacturers have paid increasing attention to product returns and recovery management, recognizing that these provide economic, social, and environmental benefits. Related initiatives have been implemented with the primary objective of reducing operating costs while simultaneously raising profits (Rogers and Tibben-Lembke, 2001). Recognizing the value of products post-use and having to meet rigid environmental regulations, many organizations have begun to expand product return programs to include recovery activities that include rework, refurbishing, recycling, remanufacturing, and remarketing (Gobbi, 2011). The desire to reduce production costs, shorten product life cycles, influence consumer preferences, and respond to legislation related to end-of-life products have led to accelerating growth in product return programs. Effective programs and environmentally responsible practices stimulate innovations in sustainability that can help firms be more competitive (Jack et al., 2010).

With increasing consumption of manufactured products in developing economies, the question of how to manage product returns takes on greater significance (Shaharudin et al., 2015a). Rapid industrialization and environmental degradation over the last two decades led the Malaysian government in particular to make sustainable production and consumption a key agenda item in its Eleventh Malaysia Plan (2016-2020). The intent was to promote sustainable business models that stressed the creation of green markets, renewable energy, demand side management, low carbon emissions, and waste reduction. Doing so creates eco-friendly businesses and sustainability practices that reduce firms' dependence on natural resources (Bell and Mollenkopf, 2013). To accomplish its objectives, the government is encouraging the private sector, and in particular manufacturers, to develop effective waste management practices by establishing an industrial ecology system to support environmental sustainability (Economic Planning Unit, 2015).

Sustainability policies in developing countries tend to motivate solutions that focus on the disposal of used goods rather than on preventing waste and emissions at the source. At present, there is no proactive effort to recover or recycle end-of-life products in Malaysia let alone returned products with significant residual value. The current waste treatment system is unsustainable, and may create serious environmental problems including illegal dumping and the increased use of landfills that adversely affect human and environmental health (Mohamed, 2009). It is thus vital that Malaysia and other developing countries with similar challenges 
develop clean production systems and embrace closed-loop supply chains (CLSC) that effectively manage both forward and reverse flows of goods and materials.

Given the increasing scope of product returns among Malaysian firms, solutions need to be found in the reverse logistics segment of the CLSC that reflect the timing, quality, quantity, and variety of returns. Past research has shown that high volumes of product returns inspire firms to adopt CLSC as they recognize the importance of reverse logistics (Mondragon et al., 2011), profitability (Guide Jr. and Van Wassenhove, 2009), competitive advantage and sustainability (Erol et al., 2010), and increased customer service and retention (Srivastava and Srivastava, 2006). However, these efforts can be adversely impacted by uncertainties in the timing, volume, and quality of returns, and where in the supply chain the return occurs (Krapp et al., 2013). These uncertainties present operational challenges to CLSC adoption (Pereira, 2018), making it imperative for manufacturers to consider them and to formulate corresponding strategies and actions (Zeballos et al., 2018).

The literature also supports the view that green capability that responds to customers' and other stakeholders' environmental concerns is the crucial enabler of a CLSC (Robotis et al., 2012). Few studies have examined green capabilities in a CLSC. For example, there is a lack of studies of firm-specific capabilities that can induce the adoption of environmental activities (Hofmann et al., 2012). Green capabilities cannot be deployed in isolation since the successful implementation of a CLSC depends on the quantity, timing, and quality of product returns in the reverse supply chain (Guide Jr. and Van Wassenhove, 2009; Mitra, 2012). Shaharudin et al., (2017) highlighted the influence of product return volume on the adoption of CLSC activities, yet despite this relationship, there is a dearth of literature discussing the mediating effects of product return volumes on CLSC adoption. Indeed, data from developing countries such as Malaysia that has been specifically retained by manufacturers for internal use only has left the field unexplored (Shaharudin et al., 2015a). Moreover, recent evidence of the contribution of product returns to environmental practices is limited (Krikke et al., 2013) despite this being vital in demonstrating the prospective value to business operations (Guide and Van Wassenhove, 2006).

This study draws on three theoretical lenses, the Resource Based View of the Firm (RBV), Natural Resource Based View (NRBV) theory, and Institutional Theory to examine whether product returns mediates the effects of green capabilities on CLSC adoption. This has important implications in motivating the development of infrastructure that can reduce material use and facilitate more environmentally friendly production. It is of particular significance in the 
context of developing economics that face the challenge of reconciling economic growth, increasing prosperity and thus consumption, and investing in environmentally sensitive production activity. Understanding the dynamics of CLSC can help mitigate the challenges associated with growth outpacing investment in basic infrastructure as is often the case in developing countries. The remainder of the article is organized as follows. The next section describes the literature related to green capabilities and closed loop supply chains and is followed by the theoretical development of the research model and details of the research method. Results and implications are then presented followed by discussion of the study's limitations and directions for future research.

\section{Literature Review}

\subsection{Theoretical Lenses}

According to RBV theory (Wernerfelt, 1984), a firm can create sustainable competitive advantage by developing and leveraging existing resources in unique ways (Barney, 1991). It suggests that resources and capabilities are critical factors in performing activities and work in the organization (Grant, 1991). Moreover, a firm's ability to execute certain activities, routines, or business processes is a function of the resources and capabilities under their control (Ray et al., 2004). A firm's green capabilities can be such a source of inimitable value if leveraged, for example, to perform value added tasks such as those in a CLSC. This can simultaneously increase value to the firm and lower cost. Successful product return management can, for example, be a precursor to effective CLSC adoption (Shaharudin et al., 2015b).

The NRBV theory (Hart, 1995) complements the RBV by considering environmental perspectives. It suggests that the prevention of pollution, product stewardship, and sustainable development can lower costs while increasing productivity and efficiency, and minimizing the life cycle environmental costs of products. A strategy founded on sustainable development may in turn raise expectations of future earnings relative to those of competitors. As such, it can motivate the development of green capabilities and the adoption of CLSCs and product return management (Robotis et al., 2012).

While both the NRBV and RBV suggest that organizational capabilities originate from resources and significantly impact competitive advantage, a key distinction is that the RBV does not consider limitations a firm may encounter in dealing with the environment (Hart, 1995). Moreover, it does not take into account how capabilities such as waste reduction and eco-design can be a source of future advantage. Firms with key green resources tend to have 
organizational capabilities that enable them to effectively deal with environmental issues using strategic processes (Judge and Douglas, 1998). Different resources contribute to the development of distinct organizational capabilities (Russo and Fouts, 1997). For example, firms with technical resources can restructure manufacturing processes to minimize environmental pollution, while those with financial resources can develop and install advanced pollution control equipment (Bae, 2017). Firms may also cultivate green capabilities such as recovery, integration, and manufacturing capabilities to counter uncertainties in the flows of product returns which can affect successful CLSC adoption. In this context, the NRBV provides a basis for understanding these capabilities relative to product stewardship (Hart and Dowell, 2011), and how managing returns/CLSC adoption can improve product life cycle costs, value chain systems, and market repositioning (Miemczyk et al., 2016).

The effects of green capabilities on CLSC adoption may, however, depend on institutional pressures originating from the government, customers, and competitors in the form of coercive, normative, and cultural-cognitive isomorphism as articulated by Institutional Theory (DiMaggio and Powell, 1983; Scott, 2001). These can manifest in the need to comply with regulatory requirements (coercive) or environmental standards required of certifications such as ISO 14001 (normative), or the desire to serve customers while securing sales in the secondary market and protecting the environment (cultural-cognitive). These pressures may motivate firms to manage the returns process to increase profit and reduce cost by adopting environmental initiatives including CLSC adoption (Shi et al., 2012). Institutional theory thus provides a basis for explaining the effects of external forces such as global competition, short product life cycles, increased environmental regulations, and retailers' liberal return policies on product returns (Guide Jr. et al., 2003b, Ye et al., 2013) and CLSC adoption.

As the three theoretical lenses suggest, the development and implementation of green capabilities motivates the need to effectively manage product returns and thus CLSC adoption. In particular, green capabilities can influence the volume and variability of product returns which can in turn influence the viability and extent of CLSC adoption. The relationships between green capabilities, product returns, and CLSC adoption, and how the three theoretical lenses frame the current study are summarized in Figure 1. 


\subsection{Green Capabilities}

Lee and Klassen (2008) used the terms green capabilities and environmental capabilities interchangeably, defining them as the assets, technologies, and expertise that firms can exploit to manage the diverse environmental needs of customers and other stakeholders. Chen and Chang (2013) argued that a firm's green dynamic capabilities are derived from their inimitable resources and knowledge in response to product returns in the fast changing marketplace. Shang et al. (2010) examined the green capabilities of Taiwanese electronics firms in terms of environmental participation, manufacturing and packaging, marketing, supply, inventory, and

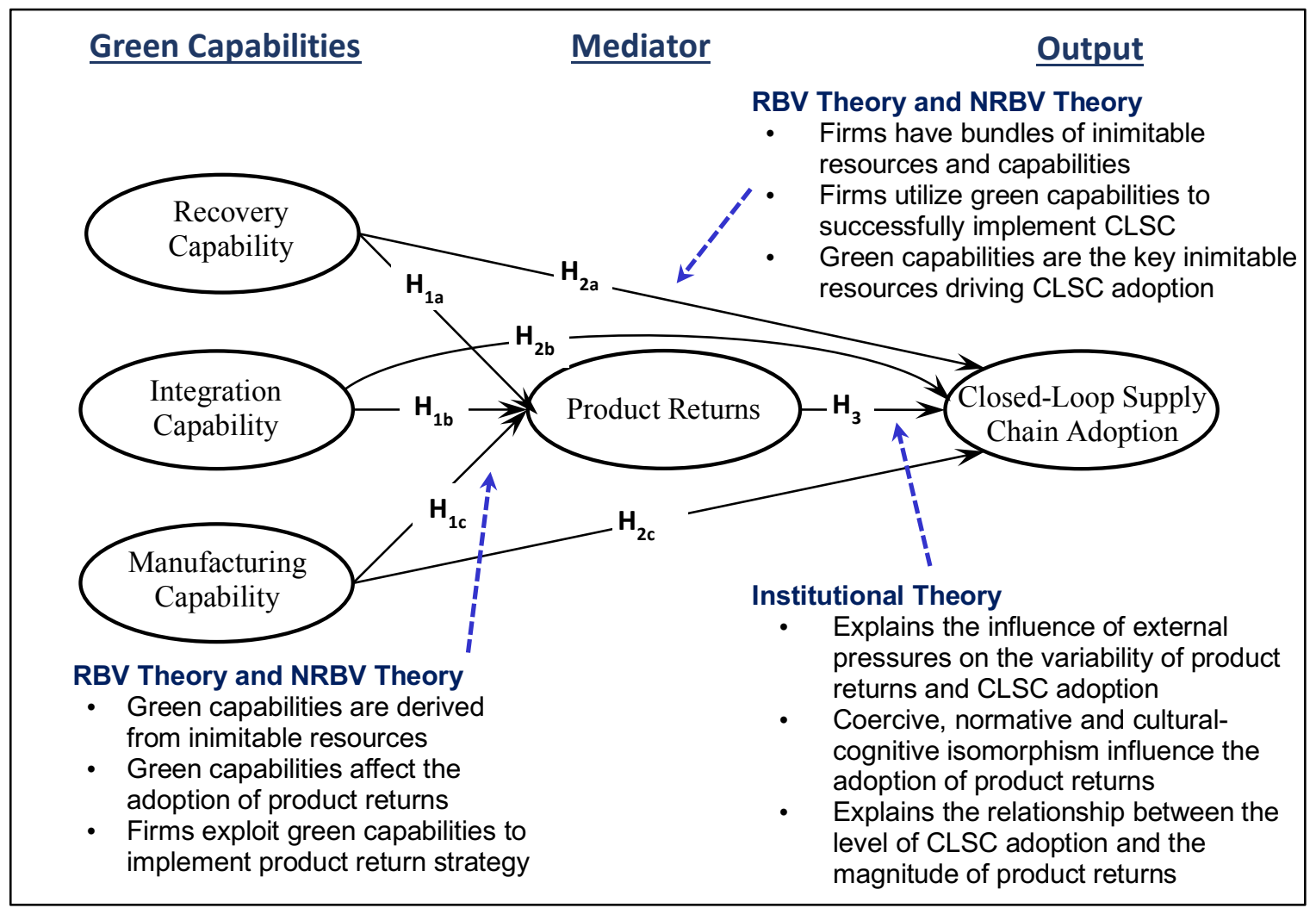

Figure 1: Research Model

eco-design. They showed that firms with green capabilities are well positioned to achieve high levels of performance. While advocating for the identification of other green capabilities and their relationships with firm performance, the study has become the basis upon which subsequent research has defined the scope of green capabilities. It should be noted that there is little evidence in the literature about which green capabilities are effective in processing product returns in a CLSC. 
Green process capability promotes the efficient use of energy and fuel that can help firms offer competitive products in the market (Hassini et al., 2012). The green capabilities of supply chains relate to internal functional flows (finance, logistics and information), integration, relationships, and environmental management that are imperative for a firm's competitive advantage (Shang et al., 2010). Facets such as green manufacturing, packing, supply, marketing, and eco-design, and environmental participation are all part of the green capabilities of the supply chain which can contribute significantly to firm performance (Shang et al., 2010). These have triggered the notion that green capabilities can serve as a catalyst for the adoption of green practices such as product return management and CLSCs in the organizations.

Although numerous facets of green capabilities have been identified in prior literature, three in particular have been discussed extensively, recovery, integration, and manufacturing capability (Table 1). These also emerged from in-depth interviews with five manufacturers during the preliminary stages of this study and have been used to operationalize green capabilities in this study.

\begin{tabular}{lll}
\hline Capability & Implications & Author \\
\hline Recovery & $\begin{array}{l}\text { Fast, efficient product returns } \\
\text { Accuracy of recovery rates }\end{array}$ & Jack et al. (2010) \\
Integration & $\begin{array}{l}\text { Effective external integration contingent } \\
\text { upon internal integration }\end{array}$ & Rizzi et al., (2013) \\
& $\begin{array}{l}\text { High volume and diverse quality of returns } \\
\text { Effective utilization of energy and material } \\
\text { Manufacturing } \\
\end{array}$ & $\begin{array}{l}\text { Hartmann and Germain (2015) } \\
\text { Limited/zero waste in production ecosystem (2001) }\end{array}$ \\
\hline
\end{tabular}

Table 1. Green Capabilities

Recovery capability is the ability to reclaim or reprocess returned products into remanufactured or new goods or useable component parts (Hassini et al., 2012). It includes the ability to provide the infrastructure needed to promptly handle product returns in the reverse supply chain (Jack et al., 2010). Companies need to build recovery capabilities using appropriate methods in CLSCs to achieve productive processes (Unruh, 2008). This involves using appropriate technology and leveraging cooperation from all parties across the supply chain (Jack et al., 2010; Tibben-Lembke and Rogers, 2002). It also includes the use of facilities with adequate storage capabilities for returned items (Akçalı et al., 2009). Huang and Wang (2016) showed that recovery capabilities can increase acquisition price, returns volume, and revenue to third parties or distributors of returned products. 
Integration capability consists of internal and external integration capability. Internal integration capability focuses on the ability to merge the forward supply chain with reverse logistics within a firm (Bernon et al., 2013; Defee et al., 2009), whereas external integration capability reflects inter-organizational coordination (Huo, 2012). Rizzi et al., (2013) argued that the success of external integration depends largely on the performance of internal integration. The return process can be enhanced by managing high volumes and a diverse quality of returns through the integration capabilities of sub-processes such as return demand, return avoidance and networking (Hartmann and Germain, 2015).

Manufacturing capability reflects the use of new manufacturing technologies, the improvement of process flows, and the reduction of production and material costs and energy usage (Talbot et al., 2007). It encompasses the use of industrial ecology systems that convert product returns and waste into usable recycled materials or components (Sarkis, 2001). It also includes the ability to use manufacturing functions that can deal with variability in product returns and the adoption of CLSCs. In this context, concepts such as clean production, green design, remanufacturing, and lean manufacturing have been proposed as being part of the production ecosystem (Rao and Holt, 2005). It is this capability that converts end-of-use products into new products from the product returns and recoveries of effective CLSC processes (Hassini et al., 2012).

\subsection{Product Returns}

Product returns occur due to commercial returns, end-of-use, end-of-life, repair, and warranty conditions (Guide and Van Wassenhove, 2009). With commercial returns, customers normally return products to retailers within a fixed time following purchase depending on store return policy. End-of-use returns occur when customers upgrade existing equipment or goods due to technological advances. End-of-life returns are of obsolete goods that have exhausted their useful lives. Rogers and Tibben-Lembke (2001) proposed that the reverse logistics systems needed to absorb returns involve reverse flow products and reverse flow packaging. From an organizational perspective, the goal of the former is to recover costs through remanufacturing, refurbishing, recycling, or other reverse logistics activities. Reverse flow packaging involves the return of items such as empty soft drink bottles for recycling or reuse.

Customers return products for a variety of reasons (Mannella, 2003; Rogers and TibbenLembke, 2001), although the actual reasons are not always easy to determine (Prahinski and 
Kocabasoglu, 2006). Customer behavior depends on the demand requirements of the return process (Shaharudin et al., 2015a) and differs from one customer to another. This makes it difficult for manufacturers to decide whether to recycle, remanufacture, or dispose of products or salvage parts, especially when the magnitude of returns is uncertain. Moshtagh and Taleizadeh (2017) showed that the volume of product returns depends on return quality, the majority of returns being of adequate quality for sale to the secondary market. However, a return strategy that streamlines reverse logistics in a CLSC can contribute significantly to a firm's economic, environmental, and social sustainability through reductions in raw materials use (White et al., 2003).

In some markets, retailers' liberal return policies, legislation on product disposal, changes in consumer preferences and market dynamics, and shorter product life cycles have rapidly fueled the volume and type of returns in the reverse logistics system (Daugherty et al., 2001; Hsiao, 2010). This has put increasing pressure on firms to embrace reverse logistics and adopt CLSCs. Indeed, many manufacturers have adopted product return management initiatives specifically to reduce waste and reverse logistics cost (Hsiao, 2010). As product life cycles shrink and consumption increases, the volume and types of product returns will continue to increase, forcing firms to incorporate reverse logistics in their CLSCs (Jayaraman and Luo, 2007). However, there must be sufficient volume of returns in a CLSC for firms to justify investing in green capabilities to process returns. The quantity, timing, and quality of returns also affect the cost and needed capabilities of reverse logistics system (Guide Jr. and Van Wassenhove, 2009; Mitra, 2012). Mollenkopf et al. (2007) suggested that a firm's marketing strategy and green policies affect the type and timing of product returns, and that this ultimately defines the extent of its involvement in the reverse logistics system. Shaharudin et al., (2015a, b) argued that green capabilities in a CLSC are required to process high volumes of product returns.

\subsection{Closed-Loop Supply Chain (CLSC)}

Wells and Seitz (2005) defined a CLSC as "consisting of two supply chains: a forward and a reverse chain; whereby, a recovered product re-enters the traditional forward chain", thereby creating a continuous loop (Andiç et al., 2012). Fleischmann et al. (2001), Guide Jr. et al. (2003a, 2003b), and Blackburn et al. (2004) described the major activities in a CLSC as

- product acquisition to repossess used items (product, part, material) from end-users 
- reverse logistics to move used items from end-of-use point to disposition point

- inspection and disposition of used items to identify their condition so that the reuse option that maximizes residual value can be determined

- deploying the best reuse option through direct reuse, repair, remanufacture, recycle, or disposal, and

- remarketing by creating and exploiting markets for refurbished goods.

A closed-loop supply chain processes all types of returns, from discarded products to endof-life products (Morana and Seuring, 2011). Manufacturers can benefit from the return of both defective and end of use products (Turki et al., 2017), the benefits being economic and environmental (Huang and Wang, 2016). Returns may occur at any stage of the forward supply chain including purchasing, manufacturing, delivery, and final consumption by end users. Moreover, substantial volume is required to sustain a viable CLSC and serve secondary market demand (Trebilcock, 2002). Reverse logistics has been widely recognized in the literature as being the key component in managing product recovery, returns, or excessive stock in a CLSC (Jayant et al., 2012). The reverse logistics component is used for part/material reclamation, remanufacturing, or disposal. Recovered products are then reinserted into the forward supply chain to feed secondary market demand (Saibani, 2010).

The type and volume of product returns in a CLSC affect the activities needed to reclaim or remanufacture returned items into useful parts or saleable goods. They also affect a firm's product acquisition strategies, reverse distribution, testing, sorting and grading, reconditioning, and remarketing (Guide Jr. and Van Wassenhove, 2001), and the life cycles of component parts (Tibben-Lembke, 2002). For example, surplus products require redistribution and reselling, whereas end-of-life products need refurbishment before their return to the forward supply chain. Different types of returns also call for different reverse logistics processes, and reclaimed goods re-enter the forward supply chain in different ways (Guide Jr. et al., 2003b).

In summary, green capabilities are a key dimension in managing the volume and variability of product returns. Manufacturers need to incorporate long term green capacity planning into managing CLSCs to determine when, where, and by how much product disposition options (reuse, recycle, remanufacture) need to be established or expanded (Georgiadis and Athanasiou, 2013). They also need to coordinate effective forecasting and return policies with investment decisions to ensure that adequate CLSC capacity exists. By having appropriate recovery capabilities, reliable inspection mechanisms can be provided to 
support the product return process (Robotis et al., 2012). Integration with suppliers to reduce variability in the sources of returns and to design processes with suppliers and customers in mind can also increase CLSC adoption among manufacturing firms (Bell and Mollenkopf, 2013). For effective CLSC adoption it is thus essential for firms to harness green capabilities to support the diversity of inbound product return flows from reverse supply chains.

\section{Research Hypotheses}

The reverse supply chain is a complex entity (Srivastava and Srivastava, 2006), and to overcome this complexity, firms must possess recovery capabilities in rework, repair and refurbish, and remanufacture sites (Krikke et al., 2013). Technical expertise in reverse operations also affects the volume of product returns. A firm's recovery capability in terms of the acquisition of essential technology, recovery equipment, and skilled workers to process waste thus affects the volume of product returns (Lau and Wang, 2009). This suggests

\section{$H_{1 a}:$ Recovery capability positively affects the volume of product returns.}

Firms that integrate their internal strategies and operations functions are more effective in handling product returns than those that do not (Mollenkopf et al. (2007). The effectiveness of returns was measured in terms of a firm's ability to handle returns regardless of their volume, timing, type, and quality. A firm's external integration capabilities also affect the volume of product returns because an effective reverse logistics system is the key to motivating product returns from customers (Diabat et al., 2013). The breaking down of departmental silos is thus key to facilitating the flow of product returns in the reverse supply chain (Mollenkopf et al., 2007) leading to the hypothesis

\section{$H_{1 b}$ : Integration capability positively affects the volume of product returns.}

Manufacturing capability is needed to handle a wide variety of product returns in a CLSC. For example, the production process must be able to respond effectively to the uncertain timing and volume of product returns, and be able to dismantle products, recover materials, coordinate new material needs, and fulfil demand (Guide Jr. et al., 2003b). A highly flexible or capable manufacturing system in the forward chain supply must be able to support product returns without sacrificing the overall production goals of the CLSC. This leads to

$H_{1 c}$ : Manufacturing capability positively affects the volume of product returns. 
Miemczyk (2008) identified thirteen unique recovery capabilities for EoL product recovery, categorizing them as either routine, technical, or revenue improving. Routine recovery capability refers to a firm's ability to influence its institutional structure through selling and its impact on present and future legislation. Technical recovery capability comprises aspects of the assessment, technology, and management of the supply chain. Revenue recovery capability relates to direct-to-customer sales programs and cost reduction activities such as revenue sharing from the sale of salvaged parts. These capabilities are important in facilitating EoL product recovery operations in CLSCs such as ensuring an adequate supply of EoL products as well as reducing reverse supply chain costs (Miemczyk, 2008). Other recovery capabilities such as inspection mechanisms (Robotis et al., 2012), recovery technology (Jack et al., 2010; Tibben-Lembke and Rogers, 2002), and reverse logistics infrastructure (Jack et al., 2010) can also support product recovery operations in CLSCs. Remanufacturing is another component of CLSC recovery activities and requires distinct capabilities from those of the forward supply chain (Ferguson and Souza, 2010). We therefore hypothesize

$H_{2 a}$ : Recovery capability positively affects the extent of CLSC adoption.

Integrated supply chains are needed to handle a dynamic environment that affects product returns and the recycling process (Mollenkopf et al., 2007). Firm-specific capabilities including possessing expert knowledge, leveraging inter-department communication, and using environmental management systems enable firms to adopt green practices ( $\mathrm{Wu}$ et al., 2012). Integration capabilities related to technology adoption, collaboration with customers and suppliers, and innovation help firms embrace environmental management practices (Hofmann et al., 2012). Miemczyk et al. (2016) argued that integration capability is particularly important with respect to sharing skills and knowledgeable employees when developing and implementing CLSC processes. This takes on particular significance when manufacturers and suppliers work together to develop CLSC processes (Defee and Fugate, 2010). These observations lead to

\section{$H_{2 b}$ : Integration capability positively affects the extent of CLSC adoption.}

An important consideration in process capability is the adoption of environmentally responsible approaches such as the use of energy efficient equipment, fuel-saving transportation, and eco-friendly raw materials and component parts to produce low cost, high quality products. In other words, manufacturers should have appropriate manufacturing capabilities to support their green objectives (Hassini et al., 2012). Firms with such capabilities 
will likely be more advanced in their CLSC deployments than those that are less environmentally focused. Manufacturing capability includes the ability to turn end-of-use products into new or remanufactured products, and to salvage recyclable parts in the CLSC. Clean production, green design, remanufacturing, reuse, and lean manufacturing all help firms reduce waste and support environmental sustainability (Rao and Holt, 2005). This suggests

\section{$\mathrm{H}_{2 c}:$ Manufacturing capability positively affects the extent of CLSC adoption.}

The volume of product returns affects the reverse supply chain component of a CLSC (Guide Jr. and Van Wassenhove, 2009; Krapp et al., 2013; Mondragon et al., 2011). A high volume of product returns is the basis for adopting CLSC (Trebilcock, 2002, Shaharudin et al., 2017). Guide Jr. and Van Wassenhove (2009) concluded that in addition to technical recovery, marketing, and sales issues, the lack of used products was a major impediment to CLSC adoption. This suggests

\section{$H_{3}: \quad$ The extent of product returns positively affects the extent of CLSC adoption.}

Talbot et al. (2007) concluded that firms that focused on both the forward and reverse supply chains in a CLSC tended to excel in their operations and were better positioned to adopt remanufacturing or CLSC activities than those focused solely on the forward supply chain. By being proactive in managing the quality, volume, and timing of product returns, firms are able to achieve a more efficient and responsive product return and recovery process (Guide Jr., 2000, Guide Jr. et al., 2001). This in turn translates to a higher degree of CLSC adoption. Miemczyk et al. (2016) argued that the diversity of volume and quality in EoL returns has created a challenge for firms in obtaining an adequate supply of sources to carry out CLSC activities. They also suggested that many firms are unable to deal with returns, which impedes their recovery capability and thus their ability to meet demand for recyclable and recycled products. We hypothesize

\section{$H_{4 a}$ : The volume, timing, quality and type of product returns mediates the relationship between recovery capability and the extent of CLSC adoption.}

Krikke et al. (2013) found that commercial and warranty returns are market driven but end-of-use and end-of-life returns are regulation driven. As a result, most businesses receive their commercial and warranty returns during the early stages of a product's life whereas endof-use and end-of-life returns are received mostly at the end of a product's life. Given the diverse characteristics of returns, sound integration capability must be deployed to manage 
product returns (Bernon et al., 2013) and increase the recovery value from adopting CLSC (Krikke et al., 2013). This includes a long-term commitment to collaboration with supply chain partners to develop processes and expand networks for mutual benefit in the CLSC system (Miemczyk et al., 2016). Increases in product returns are thus expected to increase the impact of integration capability on CLSC adoption leading to

\section{$H_{4 b}$ : The volume, timing, quality and type of product returns mediates the relationship between integration capability and the extent of CLSC adoption.}

To improve manufacturing capability in a CLSC, firms must invest in advanced production technologies, improve work conditions, reduce waste, promote the use of recovered materials and component parts, and reduce energy consumption (Talbot et al., 2007). Green concepts including clean production, green design, remanufacturing, and lean manufacturing with its focus on waste reduction have been used successfully (Rao and Holt, 2005). However, successful CLSC adoption is also contingent on the variety and volume of product returns. A CLSC is of limited value absent a sufficient volume of returns. This suggests that firms are motivated to improve their manufacturing capabilities to support a high level of returns. We therefore hypothesize

$H_{4 c}$ : The volume, timing, quality and type of product returns mediate the relationship between manufacturing capability and the extent of CLSC adoption.

\section{Methodology}

Data to test the hypotheses was collected using a survey instrument. Indicator variables were developed based on the literature review and interviews with industry professionals (Appendix). Five point Likert scales were used for all items. The instrument was pre-tested by academics and an industry professional familiar with the domain of the study. Based on their feedback, the instrument was revised to improve clarity and readability. A pilot study was then conducted using twenty supply chain professionals. Responses were received from fourteen of the twenty and suggested that the instrument was appropriate and item scales reliable.

The sampling frame consisted of all ISO 14001 certified (Environmental Management System, EMS) manufacturers in Malaysia. Malaysia is consistently among the most competitive countries according to the World Economic Forum's Global Competitiveness Index. It continues to move away from a focus on agriculture to becoming a modern manufacturing and services-based economy. The rapid industrialization Malaysia has experienced has forced it to evaluate not only its economic progress but issues of social and 
environmental sustainability that threaten its economic sustainability. While the firms in the sampling are more likely to embark on CLSC initiatives than others (Zhu et al., 2008), they can offer insights into the relationships being examined. The sampling frame was developed from the directories of the Malaysian Investment Development Authority (MIDA), the Standards and Industrial Research Institute of Malaysia (SIRIM), and the Federation of Malaysian Manufacturers (FMM). These yielded 465, 690, and 468 firms respectively. After removing duplicate listings, 600 firms remained. This was further reduced to 581 after removing companies that participated in the pilot or exploratory phases of the study. Given the size of the sampling frame and concern about obtaining only a small sample, census sampling was used, responses being sought from the entire sampling frame (Harding, 2006).

Target respondents were Supply Chain, Quality, Logistics, or Production Managers considered likely to have knowledge of issues related to CLSCs and the supply chain more broadly. An original and two follow-up surveys administered two weeks apart yielded 150 useable responses, a response rate of $25.8 \%$. Not surprisingly, more than half of the respondents came from the electrical and electronics sector, the largest industry sector in Malaysia and the one with the most ISO 14001 certified firms (Table 2).

\begin{tabular}{lcc}
\hline \multicolumn{1}{c}{ Items } & Survey Responses & \% of Responses \\
\hline \hline Job Title & 12 & \\
Senior Manager & 74 & 8.0 \\
Manager & 26 & 49.3 \\
Assistant Manager & 19 & 17.3 \\
Section Head & 13 & 12.7 \\
Other & 6 & 8.7 \\
No-response & & 4.0 \\
Department & 41 & \\
Production & 32 & 27.3 \\
Quality & 16 & 21.3 \\
Supply Chain & 33 & 10.7 \\
Logistics & 22 & 22.0 \\
Other & 6 & 14.7 \\
No-response & & 4.0 \\
Primary Business & 96 & 64.0 \\
Electrical and Electronics Products & 13 & 8.7 \\
Basic Metals, Metal Products, Machinery & 7 & 4.6 \\
Rubber and Plastic Products & 3 & 2.0 \\
Wood Products and Furniture & 1 & 0.7 \\
Chemical and Chemical Products & 30 & 20.0 \\
Other Manufacturing Sector & & \\
Number of Employees & 18 & 12.0 \\
Less than 100 & 36 & 24.0 \\
100-250 & 46 & 30.7 \\
251-500 & 25 & 16.7 \\
501-1000 & 25 & 16.7 \\
More than 1000 & & \\
& &
\end{tabular}




\begin{tabular}{lcc}
\hline \multicolumn{1}{c}{ Items } & Survey Responses & \% of Responses \\
\hline \hline Years in Business Operation & 2 & \\
$<6$ & 8 & 1.3 \\
$6-10$ & 31 & 5.3 \\
$11-15$ & 109 & 20.7 \\
$>15$ & & 72.7 \\
Ownership & 38 & 25.3 \\
$\quad$ Malaysian & 31 & 20.7 \\
Joint ventures & 74 & 49.4 \\
Foreign & 7 & 4.7 \\
Other
\end{tabular}

Table 2. Demographic Profile

To test for the presence of common method variance, Harman's one-factor test was performed using principal components factor analysis (Harman, 1976, Podsakoff and Organ, 1986). This identified eleven distinct factors with eigenvalues greater than 1.0, and which explained 69.4 percent of total variance. The first factor explained 25.86 percent of the variance. Since this does not represent a majority of the variance, it can be concluded that common method variance is absent.

\section{Statistical Analysis}

The two-step structural equation modeling approach was used to test each measurement model prior to testing the structural model (Anderson and Gerbing, 1988). The measurement models were assessed to evaluate the individual loadings of each item, composite reliability, average variance extracted (AVE), and discriminant validity. The structural model was then evaluated to determine the significance of the causal paths corresponding to the hypotheses. Sobel's Z test was used to assess the mediating effects of product returns on relationships between green capabilities (independent variables) and CLSC adoption (dependent variable, Iacobucci et al., 200). Mediation effects exist if path coefficients from the independent variable to the mediator and from the mediator to the dependent variable are statistically significant. No mediation exists if a path coefficient from an independent variable to the mediator and/or from the mediator variable to the dependent variable is insignificant. Furthermore, if the path coefficient from an independent variable to a dependent variable is

a. insignificant but the value of $Z$ is significant, complete mediation exists

b. significant and the value of $\mathrm{Z}$ is significant, partial mediation exists 
c. significant but the value of $\mathrm{Z}$ is insignificant, partial mediation in the presence of a direct effect exists

d. insignificant and the value of $\mathrm{Z}$ is insignificant, partial mediation in the absence of a direct effect exists

LISREL 8.70 was used to carry out the analysis.

\subsection{Measurement Models}

Values of Cronbach's $\alpha$ and composite reliability were all greater than 0.84 (Table 3), exceeding the value of 0.6 indicative of adequate reliability (Hair et al., 2010). Values of average variance extracted (AVE) were all greater than 0.51 , exceeding the value of 0.50 that represents evidence of convergent validity (Hair et al., 2010). To test for discriminant validity, the square root of the AVE for each construct was compared to the correlations between pairs of constructs (Hair et al., 2010). Results indicated that in each case the values exceeded the correlations among the constructs, providing evidence of discriminant validity (Table 4).

To test for overall model fit, several fit indices including those that are insensitive to sample size (GFI, AGFI, CFI, and RMSEA) were examined (Jöreskog and Sörbom, 1993). Values of all indices suggested that the measurement and structural models fit the data well (Table 5) and, in particular, met requirements for absolute, incremental, and parsimonious fit (Hair et al., 2010, Hu and Bentler, 1999).

\subsection{Structural Model}

Path coefficients indicate that recovery capability $(\beta=0.26, p<0.05)$ and integration capability $(\beta=0.49, \mathrm{p}<0.01)$ but not manufacturing capability $(\beta=-0.19, \mathrm{p}>0.05)$ positively influence product returns (Figure 2). This provides support for hypotheses $\mathrm{H}_{1 \mathrm{a}}$ and $\mathrm{H}_{1 \mathrm{~b}}$. but not $\mathrm{H}_{1 \mathrm{c}}$. Integration capability $(\beta=0.34, \mathrm{p}<0.01)$ and manufacturing capability $(\beta=0.32, \mathrm{p}<0.01)$ both influence CLSC adoption providing support for hypotheses $\mathrm{H}_{2 b}$ and $\mathrm{H}_{2 \mathrm{c}}$, but there is insufficient evidence to support hypothesis $\mathrm{H}_{2 \mathrm{a}}$ regarding the influence of recovery capability on CLSC adoption $(\beta=-0.08, p>0.05)$. Product returns positively affect CLSC adoption $(\beta=$ $0.29, \mathrm{p}<0.01$ ), providing support for hypothesis $\mathrm{H}_{3}$. 


\section{Recovery Capability (RC)}

1. Rebuilding a product where some of the parts or components are recovered or replaced

2. Introduce measures and technologies to support product recovery

3. Build up recovery processes over time

4. Quality of re-work or repair

5. Timeliness of re-work or repair

0.76

0.72

0.72

0.70

0.68

\section{Integration Capability (IC)}

1. Receive information from suppliers

2. Collaborate with suppliers for cleaner processes

3. Collaborate with suppliers to substitute materials

4. Receive information from customers

0.70

0.79

0.75

0.69

0.68

5. Collaborate with customers to substitute materials

6. Management works together well on all important decisions

\section{Manufacturing Capability (MC)}

1. Production processes are designed to reduce consumption of resources in operations

2. Substitution of polluting and hazardous materials/parts

3. Production planning and control focused on reducing waste and optimizing materials exploitation

4. Components come from environmentally or ethically sound sources

5. Process design focused on reducing energy and natural resources consumption in operations

\section{Product Returns (PR)}

1. Products/materials/components return volume

2. Products/materials/components return timing

3. Products/materials/components return quality

4. Products/materials/components return evaluation

5. Products/materials/components type

\section{The Adoption of CLSC Activities (CLSC)}

1. Acquisition of used and discarded products, components and materials

2. The condition and packaging of each return are always inspected

3. Test, sort, and store used items

4. Recycle or reuse materials from used products and components

5. Repair faults in a product

6. Recondition to extend the functional use of products 


\begin{tabular}{c|ccccc}
\hline \hline Indicator & RC & IN & MC & PR & CLSC \\
\hline \hline $\mathrm{RC}$ & $\mathbf{0 . 7 1 9}$ & & & & \\
$\mathrm{IN}$ & $.315^{*}$ & $\mathbf{0 . 7 2 4}$ & & & \\
$\mathrm{MC}$ & $.497^{*}$ & $.581^{*}$ & $\mathbf{0 . 7 1 8}$ & & \\
$\mathrm{PR}$ & $.338^{*}$ & $.412^{*}$ & $.270^{*}$ & $\mathbf{0 . 7 9 5}$ & \\
$\mathrm{CL}$ & $.328^{*}$ & $.558^{*}$ & $.509^{*}$ & $.477^{*}$ & $\mathbf{0 . 7 3 1}$ \\
\hline \hline
\end{tabular}

Correlation is significant at $\alpha=0.01$ (2-tailed)

Bold numbers are square root of AVE, non-bold numbers are inter-construct correlations $\mathrm{RC}=$ Recovery Capability, $\mathrm{IN}=$ Integration Capability, $\mathrm{MC}=$ Manufacturing Capability, $\mathrm{PR}=$ Product Returns, $\mathrm{CLSC}=$ Adoption of CLSC

Table 4: Discriminant Validity

\begin{tabular}{l|c|cccccc}
\hline \hline \multirow{2}{*}{$\begin{array}{l}\text { Goodness of Fit } \\
\text { Statistic }\end{array}$} & $\begin{array}{c}\text { Acceptable } \\
\text { Levels }\end{array}$ & \multicolumn{9}{c}{ Measurement Model } & & $\begin{array}{c}\text { Structural } \\
\text { Model }\end{array}$ \\
\cline { 3 - 8 } & & RC & IN & MC & PR & CLSC & All \\
\hline \hline$\chi^{2} /$ df & $\leq 3.0$ & 1.063 & 0.963 & 1.10 & 1.014 & 1.657 & 1.249 \\
p-values for $\chi^{2}$ & $>0.05$ & 0.373 & 0.468 & 0.355 & 0.407 & 0.084 & 0.001 \\
RMSEA & $\leq 0.08$ & 0.020 & 0.000 & 0.026 & 0.010 & 0.066 & 0.041 \\
GFI & $\geq 0.80$ & 0.99 & 0.98 & 0.98 & 0.99 & 0.97 & 0.83 \\
RMR & $\leq 0.05$ & 0.01 & 0.02 & 0.02 & 0.01 & 0.024 & 0.047 \\
SRMR & $\leq 0.08$ & 0.01 & 0.02 & 0.02 & 0.02 & 0.033 & 0.068 \\
CFI & $\geq 0.90$ & 1.00 & 1.00 & 1.00 & 1.00 & 0.99 & 0.98 \\
NNFI & $\geq 0.90$ & 1.00 & 1.00 & 1.00 & 1.00 & 0.98 & 0.98 \\
NFI & $>0.90$ & 0.99 & 0.99 & 0.99 & 0.99 & 0.98 & 0.93 \\
IFI & $\geq 0.90$ & 1.00 & 1.00 & 1.00 & 1.00 & 0.99 & 0.98 \\
RFI & $\geq 0.90$ & 0.97 & 0.98 & 0.98 & 0.97 & 0.96 & 0.92 \\
AGFI & $\geq 0.80$ & 0.96 & 0.96 & 0.96 & 0.96 & 0.91 & 0.80 \\
\hline \hline
\end{tabular}

$\mathrm{RC}=$ Recovery Capability, IN = Integration Capability, MC = Manufacturing Capability, $\mathrm{PR}=$ Product Returns, $\mathrm{CLSC}=$ Adoption of CLSC

Table 5: Goodness of Fit Indices 


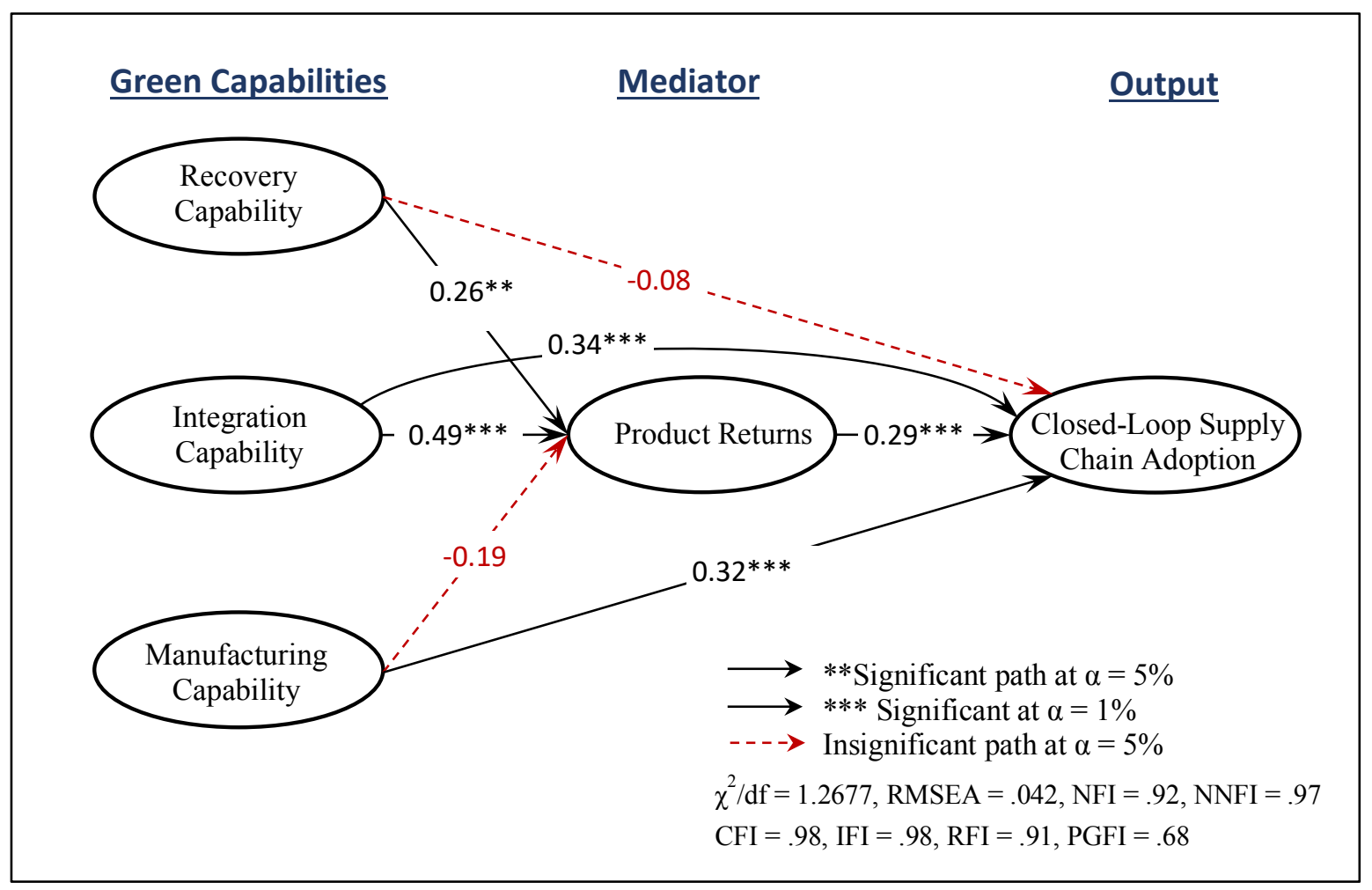

Figure 2: Structural Equation Model

\subsection{Mediating Effects}

Path coefficients from recovery capability to product returns $(\beta=0.26, \mathrm{p}<0.05)$ and from product returns to CSLC adoption $(\beta=0.29, \mathrm{p}<0.01)$ are statistically significant (Figure 3 ). However, the value of Sobel's Z statistic (1.709) and the coefficient of the path from recovery capability to CLSC are not significant. This suggests that product returns only partially mediate the relationship between recovery capability and CLSC adoption. Both the direct ( $\beta$ IC $\rightarrow$ PR $=0.49, \mathrm{p}<0.01, \beta \mathrm{PR} \rightarrow \mathrm{CLSC}=0.29, \mathrm{p}<0.01)$ and indirect $(\beta=0.34, \mathrm{p}<0.01)$ relationships between integration capability and CLSC are significant as is the value of the z-statistic (2.583). This implies that product returns partially mediates the relationship between integration capability and CLSC adoption. The insignificant path coefficient from manufacturing capability to product returns $(\beta=-0.19, \mathrm{p}>0.05)$ indicates that product returns does not mediate the relationship between manufacturing capability and CLSC adoption. 


\begin{tabular}{|c|c|c|}
\hline$\underset{--->}{\longrightarrow}$ & $\begin{array}{l}* * \text { Significant path at } \alpha=5 \% \\
* * * \text { Significant path at } \alpha=1 \% \\
\text { Insignificant path at } \alpha=5 \%\end{array}$ & $\begin{array}{l}\text { Sobel's z-test } * \quad\left(\mathrm{Ho}_{\mathrm{O}} \mathrm{a}=0 \mathrm{H}_{\mathrm{A}}: \mathrm{a} \neq 0\right) \\
\text { 2-tailed z-value }=1.960(\alpha=0.05) \\
\text { Proportion of mediation }=(\mathrm{a} \times \mathrm{b}) /(\mathrm{a} \times \mathrm{b}+\mathrm{c})\end{array}$ \\
\hline & $.26^{* *}$ & $\begin{array}{l}\text { Sobel's z-statistic }=1.709 \\
\text { Proportion of mediation }=.480 \\
\text { Conclusion } \\
\text { Insignificant direct effect (RC } \rightarrow \text { CLSC) and Sobel's z- } \\
\text { statistic implies partial mediation in absence of a direct } \\
\text { effect }\end{array}$ \\
\hline & w & $\begin{array}{l}\text { Sobel's z-statistic }=2.583 \\
\text { Proportion of mediation }=.303 \\
\text { Conclusion } \\
\text { Significant IC } \rightarrow \text { CLSC and Sobel's Z-statistic } \\
\text { implies partial mediation }\end{array}$ \\
\hline & -.19 & $\begin{array}{l}\text { Sobel's z-statistic }=-1.187 \\
\text { Proportion of mediation }=-.213 \\
\text { Conclusion } \\
\text { Insignificant } \mathrm{MC} \rightarrow \mathrm{PR} \text { implies no mediation }\end{array}$ \\
\hline
\end{tabular}

* Based on procedure suggested by Iacobucci et al. (2007)

$\mathrm{RC}=$ Recovery Capability, IN = Integration Capability, $\mathrm{MC}=$ Manufacturing Capability,

$\mathrm{PR}=$ Product Returns, CLSC $=$ Adoption of CLSC

Figure 3: Mediating Effects

\section{Discussion}

Recovery and integration capability but not manufacturing capability positively influence product returns. Manufacturing companies with recovery capability are in a position to extract additional value that comes from material recovery and the conversion of products for secondary use. This may reflect a recognition of the value associated with recovery and which may have motivated corresponding investments. These factors can influence product design, promotion, and customer service strategies that motivate product returns. Recovery capabilities and cost savings in remanufacturing have important environmental implications as they reduce the consumption of new stock and reduce the burden on landfills (Choi and Li, 2015).

Integration with suppliers enables the effective design and production of items with returns in mind. Alignment may also be an indicator of firms being more proactive and innovative in developing supply chain strategies than more firm centric organizations. This is consistent with the sample consisting of ISO 14001 certified firms. It also suggests that they may be more cognizant of the opportunities and potential value of the effective management of returns. 
Firms that respond to customer needs and market trends can modify products and otherwise respond in ways that reflect changing attitudes, of which environmental considerations are one dimension. Seeking input from customers may also reflect customer-focused sales and service strategies. This may be a precursor of more liberal return policies. The observation that manufacturing capability is not a driver of product returns is somewhat surprising. Firms' manufacturing capabilities are generally designed to support the forward supply chain rather than for remanufacturing or recycling, especially in a developing economy such as Malaysia. However, it may be that firms are not making decisions in this domain with environmental considerations in mind. In other words, manufacturing processes may already be in place and execution occurring irrespective of goals related to product returns.

Three factors motivate closed loop supply chain adoption, manufacturing capability, integration capability, and product returns. This suggests that the underlying supply chain system motivates CLSC adoption rather than unique capabilities associated with the recovery system. In the Malaysian context, the infrastructure limits a firm's ability to manage recovery activities and CLSC adoption (Shaharudin et al., 2015b). This is consistent with the assertion that firms with functional and departmental integration are more competent and accommodating in handling the return variances that affect CLSC adoption (Rizzi et al., 2013). Supply chain members must collaborate with external partners to design a complete CLSC and meet joint green and sustainability objectives (Govindan et al., 2015). Firms also need to build relationships with NGOs, institutions, and even competitors in managing product lifecycles in a CLSC (Seitz and Peattie, 2004).

The relationship between product returns and CLSC adoption is consistent with prior results (e.g., Guide Jr. and Van Wassenhove, 2009, Krikke et al., 2013). It may reflect ISO 14001 certified firms with mature supply chains recognizing the value associated with CLSC adoption and having the systems to exploit them. For electronic products and others with short life spans, the ability to quickly recapture value from returned products is of particular importance (Blackburn et al., 2004; Guide Jr. and Van Wassenhove, 2001). Given consumption patterns, failure to adopt CLSC can result in the proliferation of waste and the depletion of natural resources (Giri and Sharma, 2015). As noted earlier, electronic and electrical products producers were well represented in the sample. The results also suggest that green capabilities facilitate product returns and thus CLSC adoption. For example, effective forecasting can help reduce variation in the volume of product returns, a driver of CLSC adoption (Pereira et al., 2018). 
The finding that product returns partially mediates the relationship between recovery capability and CLSC adoption absent a direct effect between the two highlights the importance of manufacturers motivating product returns. Without an adequate volume of returns, firms may not be inclined to make new investments or redeploy resources away from activities perceived to generate greater or better understood benefits. It also illustrates, as suggested by institutional theory, how regulation such as through takeback laws that increase product returns, can motivate CLSC adoption. As observed in developed countries, sensitivity to environmental concerns has led to regulation and investment in recovery infrastructure. However, developing countries such as Malaysia tend to have few such regulations. Organizations participating in takeback programs largely do so on a voluntary basis (Agamuthu and Victor, 2011), and are typically multinational firms for whom takebacks are part of corporate social responsibility initiatives. That being said, government as well as peer pressure may create a sense of urgency for firms to increase their efforts.

Social norms and attitudes also affect product return rates yet tend to change slowly. However, high levels of product returns are likely to boost recovery capability and improve CLSC adoption (Shaharudin et al., 2015a). In addition to the direct effect described earlier, the partial mediating role of product returns highlights the indirect influence of integration capability on CLSC adoption. Firms with this capability are in a position to adopt return and warranty policies as well as processes and policies related to product design, manufacture, and quality that can influence the volume and timing of returns that drive CLSC adoption.

The finding that product return volume does not mediate the relationship between manufacturing capability and CLSC adoption implies that manufacturing capability affects CLSC adoption directly. There is a lack of incentive for manufacturers in Malaysia to invest in manufacturing capabilities to handle the product returns that might motivate CLSC adoption. They will thus continue to rely on new materials with little consideration for recycling, remanufacturing, or recapturing of used parts.

\subsection{Implications for Theory and Practice}

The results provide support for the contention of RBV, and in particular NRBV theory, that natural resources are drivers of a firm's competitiveness. Prior studies have explored internal capabilities such as green proactivity, leadership, and innovation (Hart and Dowell, 2011) and external technical capabilities (Seuring and Mueller, 2008) in the context of 
environmental management and firm competitiveness. The current study however adds recovery, integration, and manufacturing capabilities to the discussion, as well as drawing connections between green capabilities and CLSC adoption. These capabilities provide context for understanding the dynamic nature of CLSC drivers (Klassen, 2009). The results also highlight how institutional theory, as manifested through regulatory action and social and cultural norms, can be used to understand the role of product returns on CLSC adoption.

A second theoretical contribution the work makes is in providing empirical evidence of the mediating influence of product returns on relationships between recovery and integration capabilities and CLSC adoption. Prior research has highlighted relationships between both capability and product return volume on CLSC adoption. The present study provides further, more nuanced insight into the role and importance of product returns on CLSC adoption and how it can motivate capability development.

From a practical standpoint, the results highlight the importance of effectively leveraging green capabilities and of having high volume/low variability in product returns in motivating CLSC adoption. Managerial awareness of the underlying dynamics and impact of green supply chains can lead to planning and decision making that more effectively manages returns, and makes it possible to develop and implement green capabilities that motivate CLSC adoption. For example, by using 30\% recycled plastic in its computer monitors since 2015, Samsung has significantly advanced its CLSC adoption. Leveraging integration capabilities with supply chain entities including customers, eco-label certifying companies, and recovery ecosystem and environmental firms, it has increased innovation in its CLSC activity. The Galaxy S7/S7 Edge phones were produced using 60\% recycled plastic in their earphone cases, $30 \%$ percent in their inner trays, and 20\% in their chargers (Khalamayzer, 2016).

\section{Conclusions and Future Research}

This study demonstrates that consistent with the underlying premise of RBV and NRBV theories, a firm's recovery, integration, and manufacturing capabilities can be sources of competitive advantage. Moreover, combined with efforts to motivate product returns, they can provide an economic basis for adopting CLSC that provides further provide competitive benefit. While responsibility for the development of capabilities lies with the firm, external factors that might motivate this, such as regulation that increases volumes of returned parts and products, also have a role to play as suggested by Institutional Theory. 
A challenge faced by developing countries such as Malaysia is that the lack of institutional infrastructure for part/product recovery serves as an obstacle to the growth in the volume of recovered materials needed to justify firm level investments in recovery capability. While CLSC adoption can still result from investments targeted more broadly at manufacturing and integration capability, an opportunity exists if societal norms can be reframed as they relate to environmental stewardship. As consumer demand increases, developing countries will be under increasing pressure to find environmentally sound ways to manage returns and dispose of end of life products. The literature however suggests that economic benefits also accrue from the adoption of appropriate green strategies. It is thus crucial for manufacturers in these countries to recognize the importance of recovery capabilities in both influencing product returns and motivating the development of the CLSC systems that can further reduce their environmental footprint. At present, manufacturers in Malaysia largely rely on conventional manufacturing techniques, focusing exclusively on the forward supply chain. They continue to use new materials with little consideration for recycling, remanufacturing, or the recapturing of used parts that can reduce their environmental impact, reduce resource needs, or create new sources of value to the customer. There is no incentive for them to invest in new capabilities that would enable them to handle product returns or adopt CLSC, and thus enhance their competitiveness.

The study is not without its limitations. The sampling frame consisted of ISO 14001 certified firms in Malaysia meaning that the results, while significant, cannot be generalized across manufacturing sectors or geography. Certified organizations are more likely to have adopted CLSC than those that are not certified. Moreover, the sample was dominated by firms from the electrical and electronic products sector in which the value of product returns and thus of CLSC adoption may be higher than in other sectors. Further research is needed to examine whether the relationships identified in this study extend to other manufacturing firms, particularly those with significant environmental impact such as producers of textiles and/or products with short useful lives such as toys. Similarly, it is appropriate to establish whether they extend to developed economies in which recycling is an established practice, and policies, regulation, and social norms influence recycling behavior. Additional research is also needed to explore the impact of specific characteristics of product returns such as volume, variability, and timing, and to enable contingent analysis of factors such as a firm's position in the supply chain, the types of materials used in its products, and the maturity of its recycling infrastructure. 
One cannot discount the possibility that cultural norms regarding communication and having to respond to questions about one's organization and strategies influenced the responses.

The study focused only on product returns as a mediating factor in the relationship between green capability and CLSC adoption. Future research should examine the influence of other mediators of relationships between green capabilities and CSLC adoption/activity including the impact of specific characteristics of product returns to the reverse flow operations. Other authors have suggested that return processing (Stock et al., 2006), strategic and operation practices (Mollenkopf et al., 2007), regulations, incentives, contracts, monitoring, and prediction (Pokharel and Mutha, 2009), and regulatory enforcement, economic considerations, and firms' commitment (Rizzi et al., 2013) may also be pertinent variables.

\section{References}

Andiç, E., Yurt, Ö., and Baltacıŏlu, T. (2012). Green supply chains: efforts and potential applications for the Turkish market. Resources, Conservation and Recycling, 58, 50-68.

Bae, H. S. (2017). The Effect of environmental capabilities on environmental strategy and environmental performance of Korean exporters for green supply chain management. The Asian Journal of Shipping and Logistics, 33(3), 167-176.

Bell, J. E., and Mollenkopf, D. A. (2013). Natural resource scarcity and the closed-loop supply chain: a resource-advantage view. International Journal of Physical Distribution and Logistics Management, 43(5/6), 351-379.

Bernon, M., Upperton, J., Bastl, M., and Cullen, J. (2013). An exploration of supply chain integration in the retail product returns process. International Journal of Physical Distribution and Logistics Management, 43, 586-608.

Bhutta, M. K. S., Omar, A., and Yang, X. (2011). Electronic waste: a growing concern in today's environment. Economics Research International, 2011(474230), 1-8.

Blackburn, J. D., Guide Jr., V. D. R., Souz, G. C., and Van Wassenhove, L. N. (2004). Reverse supply chains for commercial returns. California Management Review, 46(2), 6-22.

Chen, Y.-S., and Chang, C.-H. (2013). The determinants of green product development performance: Green dynamic capabilities, green transformational leadership, and green creativity. Journal of Business Ethics, 116, 107-119.

Choi, T.-M., and Li, Y. (2015). Sustainability in Fashion Business Operations. Sustainability $7(12), 15400-15406$.

Daugherty, P. J., Autry, C. W., and Ellinger, A. E. (2001). Reverse logistics: The relationship between resource commitment and program performance. Journal of Business Logistics, 22(1), 107-123.

De Leeuw, S., Minguela-Rata, B., Sabet, E., Boter, J., and Sigurðardóttir, R. (2016). Tradeoffs in managing commercial consumer returns for online apparel retail. International Journal of Operations and Production Management, 36(6), 710-731. 
Defee, C. C., Esper, T., and Mollenkopf, D. (2009). Leveraging closed-loop orientation and leadership for environmental sustainability. Supply Chain Management: An International Journal, 14(2), 87-98.

Diabat, A., Kannan, D., Kaliyan, M., and Svetinovic, D. (2013). A optimization model for product returns using genetic algorithms and artificial immune system. Resources, Conservation and Recycling, 74, 156-169.

DiMaggio, P. J., and Powell, W. W. (1983). The iron cage revisited: institutional isomorphism and collective rationality in organizational fields. American Sociological Review, 48, $147-$ 160.

Economic Planning Unit. (2015). Eleventh Malaysia Plan 2016-2020. Economic Planning Unit, Prime Minister's Department, Malaysia. Retrieved from http://http//www.epu.gov.my/

Erol, I., Velioglu, M. N., Serifoglu, F. S., Büyüközkan, G., Aras, N., Çakar, N. D., and Korugan, A. (2010). Exploring reverse supply chain management practices in Turkey. Supply Chain Management: An International Journal, 15(1), 43-54.

Fleischmann, M., Beullens, P., Bloemhof-Ruwaard, J. M., and Van Wassenhove, L. N. (2001). The impact of product recovery on logistics network design. Production and Operations Management, 10, 156-173.

Genchev, S. E., Richey, R. G., and Gabler, C. B. (2011). Evaluating reverse logistics programs: a suggestion process formalization. The International Journal of Logistics Management, 22(2), 242-263.

Georgiadis, P., and Athanasiou, E. (2013). Flexible long-term capacity planning in closed-loop supply chains with remanufacturing. European Journal of Operational Research, 225(1), 44-58.

Giri, B. C., and Sharma, S. (2015). Optimizing a closed-loop supply chain with manufacturing defects and quality dependent return rate. Journal of Manufacturing System, 35, 92-111.

Gobbi, C. (2011). Designing the reverse supply chain: the impact of the product residual value. International Journal of Physical Distribution and Logistics Management, 41(8), 768796.

Govindan, K., Soleimani, H., and Kannan, D. (2015). Reverse logistics and closed-loop supply chain: a comprehensive review to explore the future. European Journal of Operational Research, 240(3), 603-626.

Grant, R. M. (1991). The resource-based theory of competitive advantage: implications for strategy formulation. California Management Review, 33(3), 114-135.

Guide, V. D. R., and Van Wassenhove, L. N. (2006). Closed-loop supply chains: an introduction to the feature issue (Part 1). Production and Operations Management, 15(3), $345-350$.

Guide Jr., V. D. R. (2000). Production planning and control for remanufacturing: industry practice and research needs. Journal of Operations Management, 18, 467-483.

Guide Jr., V. D. R., Harrison, T. P., and Van Wassenhove, L. N. (2003a). The challenge of closed-loop supply chains. Interfaces, 33(6), 3-6.

Guide Jr., V. D. R., Jayaraman, V., and Linton, J. D. (2003b). Building contingency planning 
for closed-loop supply chains with product recovery. Journal of Operations Management, 21(3), 259-279.

Guide Jr., V. D. R., Pentico, D. W., and Jayaraman, V. (2001). A framework for hierarchical planning and control for remanufacturing. In Sarkis J. (Ed.), Greener Manufacturing and Operations: From Design to Delivery and Back (pp. 273-287). Sheffield: Greenleaf Publishing.

Guide Jr., V. D. R., and Van Wassenhove, L. N. (2001). Managing product returns for remanufacturing. Production and Operations Management, 10(2), 142-155.

Guide Jr., V. D. R., and Van Wassenhove, L. N. (2009). OR FORUM--The evolution of closedloop supply chain research. Operations Research, 57(1), 10-18.

Hair, J. F., Black, W. C., Babin, B. J., and Anderson, R. E. (2010). Multivariate data analysis (7th Ed). Upper Saddle River: Prentice Hall

Harman, H. H. (1976). Modern factor analysis (3rd Ed.). Chicago, IL: University of Chicago Press.

Hart, S. L. (1995). A natural-resource-based view of the firm. The Academy of Management Review, 20(4), 986-1014.

Hart, S. L., and Dowell, G. (2011). A natural-resource-based view of the firm: fifteen years after. Journal of Management, 37(5), 1464-1479.

Hartmann, J., and Germain, R. (2015). Understanding the relationships of integration capabilities, ecological product design, and manufacturing performance. Journal of Cleaner Production, 92(2015), 196-205.

Hassini, E., Surti, C., and Searcy, C. (2012). A literature review and a case study of sustainable supply chains with a focus on metrics. International Journal of Production Economics, $140(1), 69-82$.

Hofmann, K. H., Theyel, G., and Wood, C. H. (2012). Identifying firm capabilities as drivers of environmental management and sustainability practices-Evidence from small and medium-sized manufacturers. Business Strategy and the Environment, 21, 530-545.

Holt, D., and Ghobadian, A. (2009). An empirical study of green supply chain management practices amongst UK manufacturers. Journal of Manufacturing Technology Management, 20(7), 933-956.

Hsiao, J. M. M. (2010). Building competitive advantage through innovative reverse logistics capabilities. Operations and Supply Chain Management, 3(2), 70-82.

Hu, L. T., and Bentler, P. M. (1999). Cutoff criteria for fit indices in covariance structure analysis: conventional criteria versus new alternatives. Structural Equation Modeling, 6, $1-55$.

Huang Y., and Wang Z. (2016). Closed-loop supply chain models with product take-back and hybrid remanufacturing under technology licensing, Journal of Cleaner Production, 142 (4), 3917-3927.

Huo, B. (2012). The impact of supply chain integration on company performance: an organizational capability perspective. Supply Chain Management: An International Journal, 17(6), 596-610.

Iacobucci, D., Saldanha, N., and Deng, X. (2007). A meditation on mediation : evidence that structural equations models perform better than regressions. Journal of Consumer 
Psychology, 17(2), 139-153.

Jack, E. P., Powers, T. L., and Skinner, L. (2010). Reverse logistics capabilities: antecedents and cost savings. International Journal of Physical Distribution and Logistics Management, 40(3), 228-246.

Jayant, A., Gupta, P., and Garg, S. K. (2012). Perspectives in reverse supply chain management (R-SCM): a state of the art literature review. Jordan Journal of Mechanical and Industrial Engineering, 6(1), 87-102.

Jayaraman, V. (2006). Production planning for closed-loop supply chains with product recovery and reuse: an analytical approach. International Journal of Production Research, 44(5), 981-998.

Jayaraman, V., and Luo, Y. (2007). Creating competitive advantages through new value creation: a reverse logistics perspective. Academy of Management Perspectives, 21(2), $56-73$.

Jöreskog, K. G., and Sörbom, D. (1993). LISREL 8: Structural equation modeling with the simplis command language. Chicago, IL: Scientific Software International Inc.

Judge, W. Q., and Douglas, T. J. (1998). Performance implications of incorporating natural environmental issues into the strategic planning process: An empirical assessment. Journal of Management Studies, 35(2), 241-262.

Khalamayzer, A. (2016). How Samsung, Dell are reinventing IT products. Retrieved from https://www.greenbiz.com/article/how-samsung-dell-are-reinventing-it-products

Khor, K. S., and Mohamed Udin, Z. (2012). Impact of reverse logistics product disposition towards business performance in Malaysian E and E companies. Journal of Supply Chain and Customer Relationship Management, 2012(699469), 1-19.

Klassen, R. D. (2009). Comment on the evolution of closed-loop supply chain research. In Daniel, V. G. R. Jr. and Van Wassenhove, L. N. (Eds), Operations Research - Online Forum Commentary, 57(1). Retrieved from file://C:/Users/user/Downloads/klassen.pdf

Krapp, M., Nebel, J., and Sahamie, R. (2013). Forecasting product returns in closed-loop supply chains. International Journal of Physical Distribution and Logistics Management, $43,614-637$.

Krikke, H., Hofenk, D., and Wang, Y. (2013). Revealing an invisible giant: a comprehensive survey into return practices within original (closed-loop) supply chains. Resources, Conservation and Recycling, 73, 239-250.

Lai, F., Zhang, M., Lee, D. M. S., and Zhao, X. (2012). The impact of supply chain integration on mass customization capability: an extended resource-based view. IEEE Transactions on Engineering Management, 59(3), 443-456.

Lau, K. H., and Wang, Y. (2009). Reverse logistics in the electronic industry of China: a case study. Supply Chain Management: An International Journal, 14(6), 447-465.

Lee, S.-Y., and Klassen, R. D. (2008). Drivers and enablers that foster environmental management capabilities in small and medium-sized suppliers in supply chains. Production Operations Management, 17(16), 573-586.

Mannella, M. (2003). What your returns are telling you. APICS-The Performance Advantage, $13(7), 38-44$.

Masoudipour, E., Amirian, H., and Sahraeian, R. (2017). A novel closed-loop supply chain 
based on the quality of returned products. Journal of Cleaner Production, 151(2017), 344355.

Metta, H., and Badurdeen, F. (2013). Integrating sustainable product and supply chain design : modeling issues and challenges. IEEE Transactions in Engineering Management, 60(2), $438-446$.

Miemczyk, J. (2008). An exploration of institutional constraints on developing end-of-life product recovery capabilities. International Journal of Production Economics, 115(2), $272-282$.

Miemczyk, J., Howard, M., and Johnsen, T. E. (2016). Dynamic development and execution of closed-loop supply chains: a natural resource-based view. Supply Chain Management: An International Journal, 21(4), 453-469.

Mitra, S. (2012). Inventory management in a two-echelon closed-loop supply chain with correlated demands and returns. Computers and Industrial Engineering, 62(4), 870-879.

Mohamed, A. F. (2009). Recycling systems in Malaysia: case studies on industrial waste. In Kojima, M. and E. Damanhuri (Eds.), 3R Policies for Southeast and East Asia. ERIA Research Project Report 2008-6-1, pp.53-72. Jakarta: ERIA.

Mollenkopf, D., Russo, I., and Frankel, R. (2007). The returns management process in supply chain strategy. International Journal of Physical Distribution and Logistics Management, 37(7), 568-592.

Mondragon, A. E. C., Lalwani, C., and Mondragon, C. E. C. (2011). Measures for auditing performance and integration in closed-loop supply chains. Supply Chain Management: An International Journal, 16(1), 43-56.

Montabon, F., Sroufe, R., and Narasimhan, R. (2007). An examination of corporate reporting, environmental management practices and firm performance. Journal of Operations Management, 25(5), 998-1014.

Morana, R., and Seuring, S. (2011). A three level framework for closed-loop supply chain management-Linking society, chain and actor level. Sustainability, 3(4), 678-691.

Moshtagh, M. S., and Taleizadeh, A. (2017). Stochastic integrated manufacturing and remanufacturing model with shortage, rework and quality based return rate in a closed loop supply chain. Journal of Cleaner Production, 141, 1548-1573

Pereira, M. M., Machado, R. L., Pires, S. R. I., Dantas, M. J. P., Zaluski, P. R., and Frazzon, E. M. (2018). Forecasting scrap tires returns in closed-loop supply chains in Brazil. Journal of Cleaner Production, 188, 741-750.

Podsakoff, P. M., and Organ, D. W. (1986). Self-reports in organizational research: problems and prospects. Journal of Management, 12(4), 531-544.

Pokharel, S., and Mutha, A. (2009). Perspectives in reverse logistics: a review. Resources, Conservation and Recycling, 53(4), 175-182.

Prahinski, C., and Kocabasoglu, C. (2006). Empirical research opportunities in reverse supply chains. Omega, 34(6), 519-532.

Rao, P., and Holt, D. (2005). Do green supply chains lead to competitiveness and economic performance? International Journal of Operations and Production Management, 25(9), 898-916.

Ray, G., Barney, J. B., and Muhanna, W. A. (2004). Capabilities, business processes, and 
competitive advantage: choosing the dependent variable in empirical tests of the resourcebased view. Strategic Management Journal, 25(1), 23-38.

Richey, R. G., Genchev, S. E., and Daugherty, P. J. (2005). The role of resource commitment and innovation in reverse logistics performance. International Journal of Physical Distribution and Logistics Management, 35(4), 233-257.

Rizzi, F., Bartolozzi, I., Borghini, A., and Frey, M. (2013). Environmental management of endof-life products: nine factors of sustainability in collaborative networks. Business Strategy and the Environment, 22(8), 561-572.

Robotis, A., Boyaci, T., and Verter, V. (2012). Investing in reusability of products of uncertain remanufacturing cost: the role of inspection capabilities. International Journal of Production Economics, 140(1), 385-395.

Rogers, D. S., and Tibben-Lembke, R. (2001). An Examination of Reverse Logistics Practices. Journal of Business Logistics, 22(2), 129-148.

Russo, M. V., and Fouts, P. A. (1997). A resources-based perspective on corporate environmental performance and profitability. Academy of Management Journal, 40(3), 534-559

Saibani, N. (2010). Performance Measurement for Reverse and Closed-loop Supply Chains. Unpublished Thesis, University of Nottingham.

Sarkis, J. (2001). Manufacturing's role in corporate environmental sustainability concerns for the new millennium. International Journal of Operations and Production Management, 21, 666-686.

Scott, W. R. (2001). Institutions and organizations (2nd ed.). Thousand Oaks, CA: Sage Publications.

Seitz, M., and Peattie, K. (2004). Meeting the closed-loop challenge. California Management Review, 46(2), 74-89.

Seuring, S., and Müller, M. (2008). From a literature review to a conceptual framework for sustainable supply chain management. Journal of Cleaner Production, 16(15), 16991710.

Shaharudin, M. R., Govindan, K., Zailani, S., and Tan, K. C. (2015a). Managing product returns to achieve supply chain sustainability: an exploratory study and research propositions. Journal of Cleaner Production, 101(2015), 1-15.

Shaharudin, M. R., Govindan, K., Zailani, S., Tan, K. C., and Iranmanesh, M. (2017). Product return management: linking product returns, closed-loop supply chain activities and the effectiveness of the reverse supply chains. Journal of Cleaner Production, 149(2017), $1144-1156$.

Shaharudin, M. R., Zailani, S., and Tan, K. C. (2015b). Barriers to product returns and recovery management in a developing country: investigation using multiple methods. Journal of Cleaner Production, 96(2015), 220-232.

Shang, K.-C., Lu, C.-S., and Li, S. (2010). A taxonomy of green supply chain management capability among electronics-related manufacturing firms in Taiwan. Journal of Environmental Management, 91(5), 1218-26.

Srivastava, S. K., and Srivastava, R. K. (2006). Managing product returns for reverse logistics. International Journal of Physical Distribution and Logistics Management, 36(7), 524546. 
Stock, J., Speh, T., and Shear, H. (2006). Managing product returns for competitive advantage. MIT Sloan Management Review, 48(1), 52-76.

Talbot, S., Lefebvre, É., and Lefebvre, L.-A. (2007). Closed-loop supply chain activities and derived benefits in manufacturing SMEs. Journal of Manufacturing Technology Management, 18(6), 627-658.

Tibben-Lembke, R. S. (2002). Life after death: reverse logistics and the product life cycle. International Journal of Physical Distribution and Logistics Management, 32(3), 223244.

Tibben-Lembke, R. S., and Rogers, D. S. (2002). Differences between forward and reverse logistics in a retail environment. Supply Chain Management: An International Journal, 7(5), 271-282.

Trebilcock, B. (2002). The seven deadly sins of reverse logistics. Logistics Management, 41(6), 31-34.

Turki, S. et al. (2017). Optimization and analysis of a manufacturing-remanufacturingtransport-warehousing system within a closed-loop supply chain. Sustainability, 9(561), $1-20$.

Varnavas, I. (2011). Value creation in closed loop supply chain through the implementation of product life cycle management. Retrieved from http://arno.uvt.nl/show.cgi?fid=113853

Wells, P., and Seitz, M. (2005). Business models and closed-loop supply chains: a typology. Supply Chain Management: An International Journal, 10(4), 249-251.

Wong, C. W. Y., Lai, K., Shang, K. -C., Lu, C. -S., and Leung, T. K. P. (2012). Green operations and the moderating role of environmental management capability of suppliers on manufacturing firm performance. International Journal of Production Economics, 140(1), 283-294.

Wu, G. -C., Ding, J. -H., and Chen, P. -S. (2012). The effects of GSCM drivers and institutional pressures on GSCM practices in Taiwan's textile and apparel industry. International Journal of Production Economics, 135(2), 618-636.

Ye, F., Zhao, X., Prahinski, C., and Li, Y. (2013). The impact of institutional pressures, top managers' posture and reverse logistics on performance-Evidence from China. International Journal of Production Economics, 143(1), 132-143.

Zeballos, L. J., Mendez, C. A., and Barbosa-Povoa, A. P. (2018). Integrating decisions of product and closed-loop supply chain design under uncertain return flows. Computers and Chemical Engineering, 112, 211-238.

Zhu, Q., Sarkis, J., Cordeiro, J. J., and Lai, K. H. (2008). Firm-level correlates of emergent green supply chain management practices in the Chinese context. Omega, 36(4), 577-591. 


\section{Appendix: Measurement Items*}

Recovery Capability: Likert Scale, 1= Not Capable 5= Extremely Capable

\begin{tabular}{|l|l|}
\hline Item & \multicolumn{1}{|c|}{ Source } \\
\hline $\begin{array}{l}\text { 1. Rebuilding a product where some parts or components are recovered or } \\
\text { replaced }\end{array}$ & Montabon et al., (2007) \\
\hline 2. Introduce measures and technologies to support product recovery & Miemczyk (2008) \\
\hline 3. Build up recovery processes over time & \multirow{2}{*}{ Richey et al. (2005) } \\
\hline 4. Quality of re-work or repair & 5. Timeliness of re-work or repair
\end{tabular}

Integration Capability: Likert Scale, 1= Not Capable 5= Extremely Capable

\begin{tabular}{|l|l|}
\hline Item & \multirow{2}{*}{ Source } \\
\hline 1. Receive information from suppliers & \multirow{2}{*}{ Hofmann et al. (2012) } \\
\cline { 1 - 1 } 2. Collaborate with suppliers for cleaner processes & \\
\cline { 1 - 1 } 3. Collaborate with suppliers to substitute materials & \\
\cline { 1 - 2 } 4. Receive information from customers & Lai et al., (2012) \\
\cline { 1 - 2 } 5. Collaborate with customers to substitute materials &
\end{tabular}

Manufacturing Capability: Likert Scale, 1= Not Capable 5= Extremely Capable

\begin{tabular}{|l|l|}
\hline Item & \multicolumn{1}{|c|}{ Source } \\
\hline $\begin{array}{l}\text { 1. Production processes are designed to reduce consumption of resources } \\
\text { in operations }\end{array}$ & Wong et al. (2012) \\
\hline 2. Substitution of polluting and hazardous materials/parts & Shang et al. (2010) \\
\cline { 1 - 2 } $\begin{array}{l}\text { 3. Production planning and control are focused on reducing waste and } \\
\text { optimizing the use of materials }\end{array}$ & Holt and Ghobadian (2009) \\
\cline { 1 - 2 } 4. Components come from environmentally or ethically sound sources & Shang et al. (2010) \\
\hline $\begin{array}{l}\text { 5. Process design is focused on reducing energy and natural resource } \\
\text { consumption in operations }\end{array}$ & S
\end{tabular}

Volume of Product Returns: Likert Scale, 1= Very Low Volume, 5= Very High Volume

\begin{tabular}{|l|l|}
\hline Item & Source \\
\hline 1. Volume of returned products/materials/parts/components & \multirow{2}{*}{ Guide Jr. et al. (2003b) } \\
\cline { 1 - 1 } 2. Timing of returned products/materials/parts/components & \\
\hline 3. Quality of returned products/materials/parts/components & \multirow{2}{*}{ Mollenkopf et al. (2007) } \\
\hline 4. Evaluation of returned products/materials/parts/components & \\
\cline { 1 - 2 } 5. Type of returned products/materials/parts/components &
\end{tabular}

Extent of CLSC Adoption Activities: Likert Scale, 1= Very Low Extent, 5= Very High Extent

\begin{tabular}{|l|l|}
\hline Item & \multicolumn{1}{c|}{ Source } \\
\hline 1. Acquire used and discarded products, components, and materials & Jayaraman (2006) \\
\hline 2. The condition and packaging of each return is always inspected & Genchev et al. (2011) \\
\hline 3. Testing, sorting, and storage of used items & Varnavas, (2011) \\
\cline { 1 - 1 } 4. Recycle to reuse materials from used products and components. & \multirow{2}{*}{ Khor and Mohamed Udin (2012) } \\
\cline { 1 - 1 } 5. Repair to correct defects in a product & \\
\cline { 1 - 1 } 6. Recondition to extend the functional use of products. & Varnavas, (2011) \\
\cline { 1 - 2 } 7. Sale and marketing of reusable items &
\end{tabular}

